\title{
DE GOUVERNEUR-GENERAAL WILLEM BENJAMIN VAN PANHUYS DOOR
}

\author{
JHR. L. C. VAN PANHUYS
}

Het valt niet licht over het leven van dezen Gouverneur-Generaal, na Mauricius, den tweeden G.G., van Suriname, een duidelijk overzicht te verkrijgen. Familieberichten vermelden, dat hij, op 5 December 1764 te Maastricht geboren, de oudste was van een twaalftal broeders en zusters; dat zijn vader $\mathrm{Mr}$. Huybert Aemilius in 1793 overleed en dat zijn grootvader

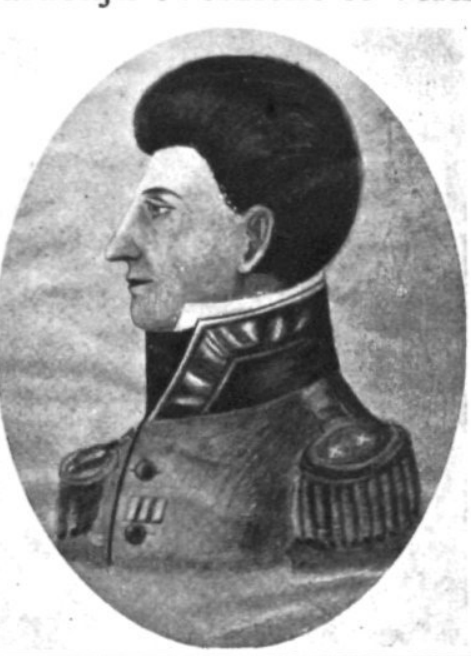
van vaderszijde, Mr. Hendrik Aemilius, die elf zoons en dochters had, in 1789 op 91jarigen leeftijd stierf. Grootvader en vader, die Willem Benjamin, evenals zijne grootmoeder en moeder, nog

langen tijd heeft gekend, waren regenten, die tevens eene betrekking bij de rechterlijke macht bekleedden. De eerste was namelijk Commissaris-Instructeur van Hare Hoogmogenden en Drossaart van het Land van Daelhem (Valkenburg), de tweede Luitenant-Drossaart of Drossaart van het Land van Daelhem en Herzogenrade (Rolduc), tevens Proost-schout te Meerssen, terwijl beiden bovendien de betrekkingen vervulden van secretaris van den Hoogen Brabantschen Geregte en van secretaris of schepen van de Grafelijkheid van de Vroenhove te Maastricht. Van 